\title{
Evaluasi Metode Aerial Videogrametri untuk Rekonstruksi 3D Bangunan (Studi Kasus: Candi Singasari, Jawa Timur)
}

\author{
Yugie Nanda Pranata dan Agung Budi Cahyono \\ Jurusan Teknik Geomatika, Fakultas Teknik Sipil dan Perencanaan, Institut Teknologi Sepuluh Nopember (ITS) \\ Jl. Arief Rahman Hakim, Surabaya 60111 Indonesia \\ e-mail: agungbc@geodesy.its.ac.id
}

\begin{abstract}
Abstrak-Candi Singasari merupakan salah satu situs warisan dunia dimana upaya untuk konservasi, inventarisasi, dan dokumentasi cagar budaya tersebut diperlukan. Sebagai langkah awal yang dapat dilakukan adalah membentuk model rekosntruksi 3D Candi Singasari. Adapun teknologi yang ditawarkan dalam pemodelan rekonstruksi 3D bangunan begitu bervariasi dengan kelebihan dan kelemahan masing-masing seperti teknologi LiDAR, laser scanner, dan fotogrametri jarak dekat. Dewasa ini, perkembangan dalam dunia fotogrametri untuk kegiatan pemodelan 3D begitu pesat hingga adanya metode yang berkembang saat ini yaitu metode videogrametri. Penelitian ini menggunakan teknologi videogramteri dan konsep SfM untuk membentuk rekonstruksi 3D Candi Singasari. Teknologi videogrametri memiliki kelebihan seperti akuisisi data yang sederhana, harga ekonomis, minim perubahan fotometrik dalam gambar, dan daya overlap tinggi dari data yang dihasilkan. Kriteria yang digunakan dalam rekonstruksi 3D Candi Singasari menggunakan klasifikasi Level of Detail (LoD). Pada penelitian ini difokuskan pada dua aspek yaitu aspek evaluasi visual rekonstruksi 3D dan perhitungan nilai ketelitian geometrik struktur Candi Singasari. Hasil evaluasi visual rekonstruksi 3D diperoleh bentuk point cloud sejumlah 308.248 titik, dense cloud sejumlah 1.126.457 titik, dan textured yang meliputi 225.291 titik (permukaan/face) dan 113.595 vertex dari 161 frame video dengan rata-rata deteksi fitur tiap frame video sejumlah 2.242 titik yang diolah menggunakan konsep structure from motion (SfM). Sedangkan evaluasi untuk validasi nilai geometrik struktur Candi Singasari diperoleh dari hasil korelasi dan uji standar kesalahan. Hasil korelasi antara variabel ICP ukuran model rekonstruksi 3D terhadap ukuran di lapangan menunjukkan nilai kolerasi untuk koordinat easting 0.998, koordinat northing 0.997 , dan koordinat $\mathrm{Z}$ 0.998. Adapun untuk nilai uji standar kesalahan untuk koordinat easting diterima $83 \%$, koordinat northing diterima $91.7 \%$, dan koordinat $\mathrm{Z}$ diterima $91.7 \%$ juga nilai RMSE koordinat easting 0.177 meter, northing 0.194 meter, dan koordinat $\mathrm{Z} 0.168$ meter.
\end{abstract}

Kata Kunci-Candi Singasari, Teknologi Videogrametri, LoD, dan SfM.

\section{PENDAHULUAN}

$\mathrm{C}$ ANDI SINGASARI di Jawa Timur merupakan salah satu kekayaan arsitektur nusantara yang mempunyai karakter lokal sebagai bangunan pada masa Kerajaan Singasari di abad ke-13 $3^{[1]}$. Banyak penelitian yang dilakukan terhadap candi, tetapi lebih menyoroti pada tafsir-tafsir historis, sehingga diperlukan penelitian yang bersifat fundamental sebagai upaya konservasi cagar budaya di Indonesia berupa rekonstruksi 3D bangunan.
Metode aerial videogrametri merupakan metode pendekatan dari metode fotogrametri jarak dekat menggunakan sensor kamera yang dipasang di wahana pesawat tanpa awak untuk proses perekaman struktur bangunan. Metode aerial videogrametri mempunyai kelebihan dari segi harga ekonomis untuk pengadaan alat dalam proses akuisisi data yang sederhana, keterampilan operator yang tidak terlalu tinggi untuk kegiatan pemodelan rekonstruksi 3D bangunan, minim perubahan fotometrik dalam gambar, dan presentase tinggi pada overlap gambar yang berdekatan ${ }^{[2]}$.

Structure from Motion (SfM) merupakan prinsip seperti fotogrametri stereskopik untuk menghasilkan struktur 3D. Teknik SfM membutuhkan foto yang saling overlap sebagai input algoritma scale invariant feature transform (SIFT) untuk ekstrasi fitur dan rekonstruksi 3D ${ }^{[3]}$. Sehingga teknik SfM sangat sesuai untuk sekumpulan gambar struktur objek 3D dengan tingkat overlap yang tinggi ${ }^{[4]}$.

Proses pembuatan rekonstruksi 3D bangunan mempunyai tingkat kedetailan rekonstruksi yang dihasilkan. Tingkat kedetailan tersebut disebut dengan level of detail (LOD) yang meliputi LOD 0 (regional model berupa digital terrain model), LOD 1 (city/site model berupa blok tanpa atap), LOD 2 (city/site model berupa model dengan tekstur dan struktur atap sederhana), LOD 3 (city/site model berupa arsitektur dengan tekstur dan struktur atap sederhana), dan LOD 4 (interior model berupa model arsitektur dari interor bangunan $)^{[5]}$.

Dikarenakan objek yang diteliti berupa rekonstruksi 3D Candi Singasari memiliki dimensi yang cukup besar dan berdasarkan kelebihan metode aerial videogrametri yang didukung dengan prinsip SfM, maka pada penelitian ini mencoba memanfaatkan metode aerial videogrametri untuk memodelkan bentuk rekonstruksi 3D bangunan Candi Singasari dengan kelas LOD 3.

Aspek lain yang perlu diperhatikan dalam rekonstruksi 3D bangunan Candi Singasari adalah perhitugan geometriknya yang diperoleh dari perbandingan ukuran langsung dari lapangan dan hasil ukuran dari bentuk visual rekonstruksi 3D bangunan untuk mendukung bentuk visual rekonstruksi 3D dengan kelas LOD $3^{[6]}$. Ukuran pembanding yang digunakann untuk perhitungan geometrik menggunakan koordinat ICP (Independent Check Point) yang diperoleh menggunakan teknik pengikatan ke muka $^{[7]}$.

Metode aerial videogrametri mempunyai potensi yang besar untuk memberikan cara yang efektif dan efesien untuk memperoleh bentuk visual rekonstruksi 3D bangunan dibanding 
metode yang pernah ada sebelumnya seperti teknologi LiDAR (Light Detection and Ranging) dan Laser Scanner ${ }^{[8]}$. Pada penelitian ini difokuskan pada dua aspek yaitu evaluasi visual rekonstruksi 3D dan perhitungan nilai ketelitian geometrik struktur Candi Singasari.

\section{METODOLOGI PENELITIAN}

\section{A. Data dan Peralatan}

\section{1) Data}

Data yang diperlukan dalam penelitian ini meliputi bidang kalibrasi kamera 2D berupa gambar (frame video) papan catur (chessboard), data spesifikasi Dji Phantom 3 Adv. 1080P60 Camera (on board), data ukuran GCP (Ground Control Point) dan ICP (Independent Control Point) pada Candi Singasari yang diukur dengan metode pengikatan ke muka dengan toleransi pengukuran sudut $5^{\prime \prime} \sqrt{\mathrm{n}}$ dan kesalahan linier $<1: 2500$, dan data frame video yang diperoleh dari hasil perekaman menggunakan metode aerial videogrametri yang sudah diekstraksi.

\section{2) Peralatan}

Perlatan yang digunakan pada penelitian ini meliputi:

1. Perangkat Keras

a. Dji Phantom 3 Adv. 1080P60 Camera (on board) $12.4 \mathrm{M}$

b. Electronic Total Station (ETS)

c. Dua set GPS Geodetik

d. Laptop

2. Perangkat Lunak

a. Program pengolah data raster (fotogrametri)

b. Program pengolah angka dan teks

c. Program plotting koordinat

\section{B. Tahapan Pengolahan Data}

Tahapan pengolahan data pada penelitian ini adalah sebagai berikut:

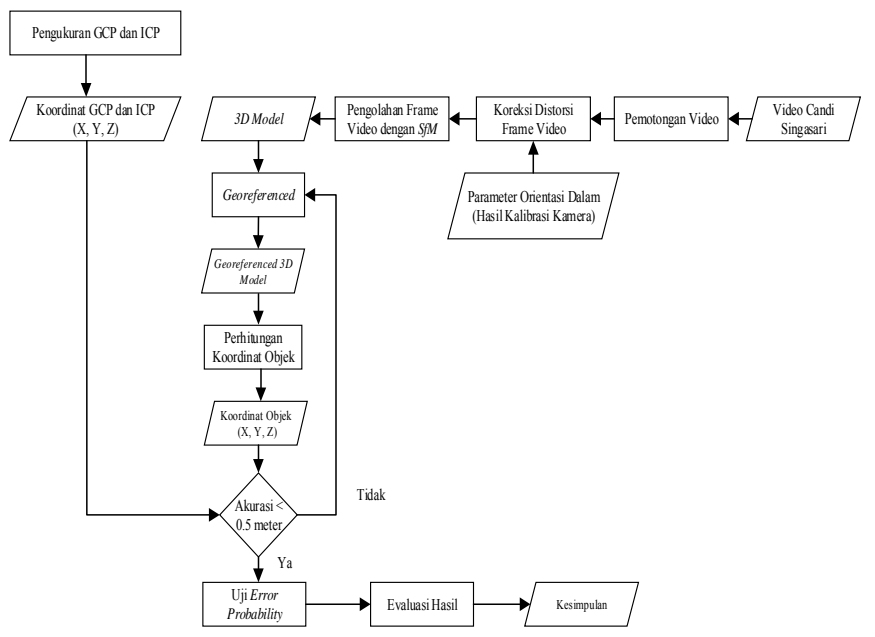

Gambar 2.1 Diagram Alir Penelitian

Penjelasan diagram alir di atas sebagai berikut.

1. Kalibrasi Kamera

Kalibrasi kamera dilakukan dengan menggunakan program pengolah angka menggunakan prinsip Bundle Adjustment Self Calibration (BASC) untuk memperoleh nilai parameter orientasi dalam (IOP), yaitu panjang fokus kamera (f), koordinat principal point $\left(\mathrm{x}_{0}, \mathrm{y}_{0}\right)$ serta distorsi radial dan tangensial (k1, k2, k3, p1 dan p2) yang digunakan untuk koreksi distorsi pada frame video.

2. Perekaman Struktur Candi Singasari

Perekaman struktur Cadi Singasari dilakukan di udara menggunakan metode aerial videogrametri dengan mode perekaman FHD (Full High Definition) 1920x1080p.

3. Pengukuran Kerangka Dasar, GCP, dan ICP

Data pengukuran kerangka dasar merupakan acuan untuk penentuan GCP dan ICP dalam sistem kooridnat UTM pada struktur bangunan candi. Koordinat GCP dan ICP ini digunakan sebagai ukuran referensi untuk menentukan unsur-unsur objek penelitian yang tampak di frame video struktur Candi Singasari.

4. Pemodelan Rekonstruksi 3D Candi Singasari

Pemodelan rekonstruksi 3D Candi Singasari menggunakan prinsip structure from motion (SfM) yang dipadu dengan algoritma scale invariant feature transform (SIFT) untuk membentuk visual 3D dasar berupa point clouds. Selanjutnya, hasil dari point clouds ini akan dilakukan evaluasi visual $3 \mathrm{D}$ dan perhitungan nilai geometrik struktur Candi Singasari.

\section{HASIL DAN ANALISA}

\section{A. Kalibrasi Kamera}

Kalibrasi kamera menggunakan prinsip BASC digunakan untuk mengetahui nilai IOP. Hasil kalibrasi kamera sebagai berikut.

Tabel 3.1 Parameter Orientasi Dalam

\begin{tabular}{ccc}
\hline \hline IOP & Nilai (pixel) & Nilai (mm) \\
\hline $\mathbf{f}$ & 2343.6 & 3.98693 \\
$\mathbf{X}_{\mathbf{0}}$ & 5.54389 & 3.41784 \\
$\mathbf{Y}_{\mathbf{0}}$ & -9.05776 & 1.89886 \\
$\mathbf{K}_{\mathbf{1}}$ & 0.0119496 & -0.00104433 \\
$\mathbf{K}_{\mathbf{2}}$ & -0.0340456 & 0.000228576 \\
$\mathbf{K}_{\mathbf{3}}$ & 0.0136146 & $-1.47295 \mathrm{e}-05$ \\
$\mathbf{P}_{\mathbf{1}}$ & 0.000623658 & -0.000147993 \\
$\mathbf{P}_{\mathbf{2}}$ & -0.00177962 & 0.000426848 \\
\hline \hline
\end{tabular}

Kamera dengan resolusi tinggi dan distorsi yang rendah masih dapat digunakan untuk keperluan fotogrametri, namun kamera dengan distorsi lensa yang lebih besar disebut dengan kamera reconnaissance yang didesain untuk keperluan interpretasi dan inventarisasi. Kamera jenis ini adalah kamera multipsektral dengan panjang fokus $35 \mathrm{~mm}-70 \mathrm{~mm}^{[9]}$.

\section{B. Pemodelan Rekonstruksi 3D}

Pengolahan data berupa frame video sejumlah 161 frame yang dilah menggunakan prinsip SfM. Hasil dari pengolahan data frame video berupa point clouds, selanjutnya dilakukan texturing agar terlihat reperesentatif seperti bentuk bangunan aslinya. Berikut adalah hasil dari pemodelan rekonstruksi 3D: 


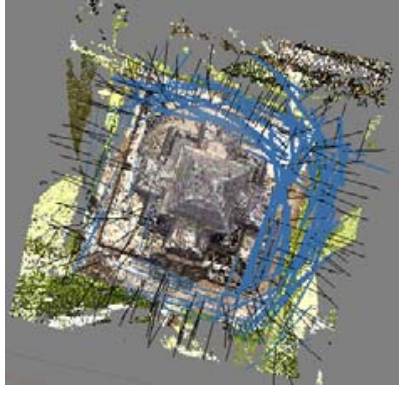

Gambar 3.1 Posisi Perekaman Strukstur Candi

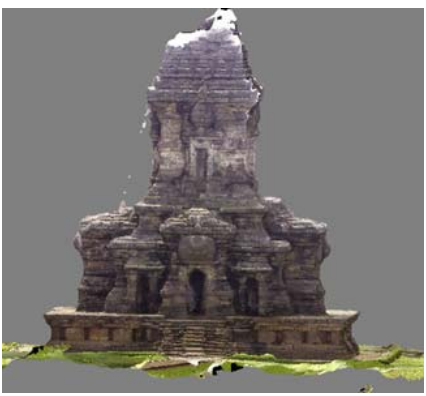

Gambar 3.2 Model Rekonstruksi 3D

Pemodelan rekonstruksi 3D menggunakan prinsip SfM mempunyai parameter pembentuk model 3D. Secara garis besar ada tiga parameter yang dapat dilihat pada tabel berikut ini. Tabel 3.2 Parameter Pemodelan 3D

\begin{tabular}{cc}
\hline \hline Parameter & Hasil \\
\hline Point clouds & 308248 point \\
Dense Cloud & 1126457 point \\
Textured & 113595 (vertex) \\
& \\
\hline \hline
\end{tabular}

Dari 161 frame video yang digunakan, rata-rata fitur terdeteksi untuk setiap frame video sejumlah 2.242 titik, fitur deteksi ini menggunakan algoritma scale invariant feature transform (SIFT) pada perangkat lunak data raster. Algoritma ini mengidentifikasi fitur tiap gambar yang tetap pada scaling dan rotasi gambar yang sedikit berubah pada kondisi iluminasi dan sudut pandang 3D kamera. Pada foto terdapat keypoint yang diidentifikasi secara otomatis di seluruh skala dan lokasi pada tiap gambar dan diikuti dengan pembuatan feature descriptor yang dihitung dengan mentransformasikan gradien gambar lokal ke dalam representasi yang sangat tidak sensitif terhadap berbagai iluminasi dan orientasi ${ }^{[10]}$. Berikut grafik fitur yang terdeteksi untuk setiap frame video.

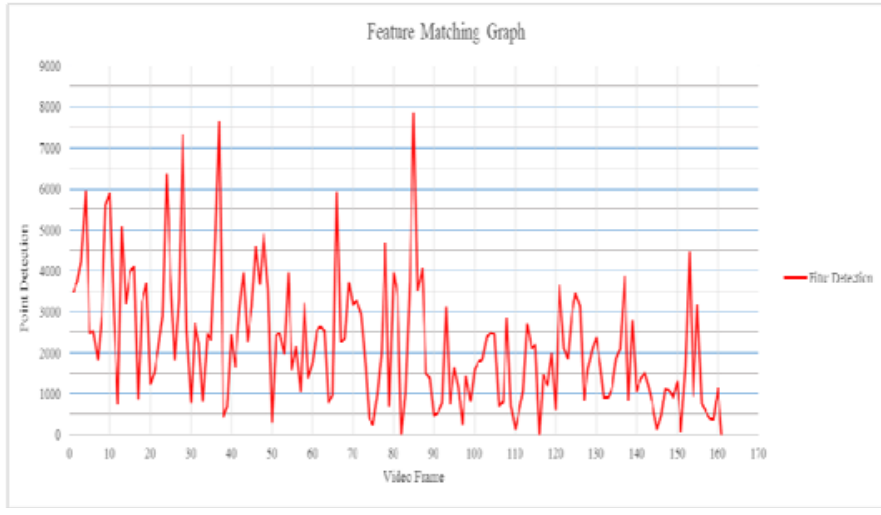

Gambar 3.3 Grafik Deteksi Fitur Frame Video

\section{Kerangka Dasar, GCP, dan ICP}

Sistem koordinat yang digunakan untuk pengukuran kerangka dasar adalah sistem koordinat Universal Transverse Mercator (UTM). Kerangka dasar ini diukur menggunakan GPS Geodetik dengan metode Differential Positioning, yaitu penentuan posisi suatu titik secara relatif terhadap lainnya yang telah diketahui koordinatnya ${ }^{[11]}$ dan Total Station membentuk kerangka dasar berupa poligon tertutup. Hasil koordinat titik poligon ditunjukkan dalam tabel berikut.

Tabel 3.3 Koordinat Titik Poligon

\begin{tabular}{cccc}
\hline Titik & Easting (m) & Northing $(\mathbf{m})$ & $\mathbf{Z}(\mathbf{m})$ \\
\hline $\mathbf{1}$ & 683434.769 & 9127721.154 & 20.000 \\
$\mathbf{2}$ & 683461.723 & 9127705.018 & 19.994 \\
$\mathbf{3}$ & 683479.134 & 9127733.700 & 20.155 \\
$\mathbf{4}$ & 683455.201 & 9127749.714 & 20.135 \\
\hline \hline
\end{tabular}

Hasil perhitungan dari kerangka dasar ini mempunyai nilai kesalahan penutup sudut sebesar 8". Kerangka dasar ini digunakan sebagai titik kontrol pengukuran GCP dan ICP pada Candi Singasari menggunakan metode pengikatan ke muka.

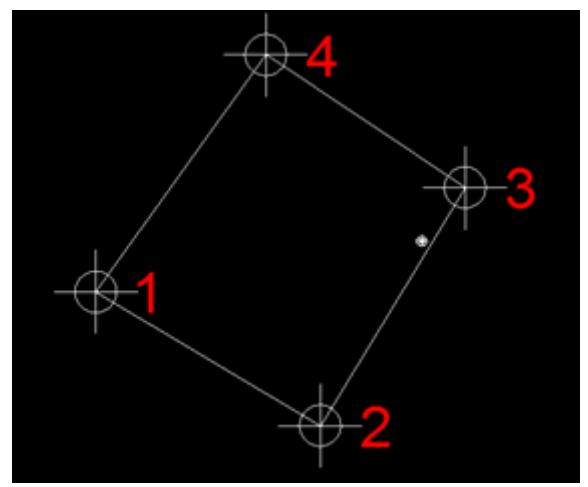

Gambar 3.4 Kerangka Dasar Pengukuran 
Analisa kerangka dasar hasil pengukuran di lapangan ditinjau dari dua kriteria yaitu:

a. Kesalahan linier

Kesalahan linier pada umumnya mempunyai standar minimal yaitu $1: 2500$ atau $0.0004^{[12]}$. Apabila kesalahan linier yang dihasilkan kurang dari 1:2500 maka hasil pengukuran kerangka dasar dapat diterima.

b. Kesalahan penutup sudut

Kesalahan penutup sudut pada kerangka dasar ini mempunyai nilai sebesar 8" yang didapatkan dari persamaan kesalahan penutup sudut yang memenuhi toleransi $5 " \sqrt{ } \mathrm{n}(5 " \sqrt{4}=10 "){ }^{[7]}$. Apabila kesalahan penutup sudut kerangka dasar setelah dikoreksi mempunyai nilai kurang dari 10" maka hasil pengukuran kerangka dasar dapat diterima.

c. Kesalahan penutup tinggi

Kesalahan penutup tinggi pada kerangka dasar ini mempunyai nilai sebesar $2 \mathrm{~mm}$ yang didapatkan dari persamaan kesalahan penutup tinggi yang memenuhi toleransi $8 \sqrt{ } \mathrm{D}(\mathrm{km})(8 \sqrt{ } 0.12888=2.872 \mathrm{~mm})^{[7]}$.

Tabel 3.4 Kesalahan Kerangka Dasar

\begin{tabular}{ccc}
\hline \hline No. & Kriteria & Nilai \\
\hline $\mathbf{1}$ & Kesalahan Linier & $0.00021 \mathrm{~m}$ \\
$\mathbf{2}$ & Kesalahan Penutup Sudut & $8^{\prime \prime}$ \\
$\mathbf{3}$ & Kesalahan Penutup Tinggi & $2 \mathrm{~mm}$ \\
\hline \hline
\end{tabular}

Adapun titik kontrol (GCP dan ICP) pada penelitian ini merupakan titik-titik yang diambil pada struktur Candi Singasari yang diukur menggunakan metode pengikatan ke muka. GCP dan ICP digunakan dalam proses geo-referencing sedangkan ICP digunakan sebagai titik pembanding antara ICP hasil pengukuran di lapangan dan hasil dari model rekonstruksi 3D. Hasil perhitungan GCP dan ICP ditunjukkan dalam tabel berikut.

Tabel 3.5 Koordinat GCP dan ICP Struktur Candi Singasari

\begin{tabular}{cccc}
\hline \hline \multirow{2}{*}{ Titik } & \multicolumn{2}{c}{ Pengukuran di Lapangan } & \\
\cline { 2 - 4 } & Easting $(\mathbf{m})$ & Northing $(\mathbf{m})$ & $\mathbf{Z}(\mathbf{m})$ \\
\hline GCP 1 & 683428.414 & 9127749.611 & 22.024 \\
GCP 2 & 683433.471 & 9127738.039 & 22.026 \\
GCP 3 & 683445.033 & 9127743.164 & 22.028 \\
GCP 4 & 683439.920 & 9127754.710 & 22.030 \\
ICP 1 & 683431.391 & 9127748.566 & 25.124 \\
ICP 2 & 683438.115 & 9127751.475 & 25.111 \\
ICP 3 & 683441.156 & 9127744.082 & 25.105 \\
ICP 4 & 683434.562 & 9127741.188 & 25.106 \\
ICP 5 & 683434.120 & 9127747.622 & 29.710 \\
ICP 6 & 683437.948 & 9127748.176 & 29.706 \\
ICP 7 & 683435.454 & 9127743.040 & 29.711 \\
\hline \hline
\end{tabular}

\begin{tabular}{cccc}
\hline \hline ICP 8 & 683439.587 & 9127745.496 & 29.709 \\
ICP 9 & 683437.979 & 9127749.294 & 31.670 \\
ICP 10 & 683433.351 & 9127747.019 & 31.675 \\
ICP 11 & 683435.576 & 9127743.396 & 31.676 \\
ICP 12 & 683439.321 & 9127745.644 & 31.672 \\
\hline \hline
\end{tabular}

Tabel 3.6 Koordinat ICP dari Pemodelan Rekonstruksi 3D

\begin{tabular}{cccc}
\hline \hline \multirow{2}{*}{ Titik } & \multicolumn{2}{c}{ Pemodelan Rekonstruksi 3D } & \\
\cline { 2 - 4 } & Easting $(\mathbf{m})$ & Northing $(\mathbf{m})$ & $\mathbf{Z}(\mathbf{m})$ \\
\hline ICP 1 & 683431.572 & 9127748.396 & 25.276 \\
ICP 2 & 683438.307 & 9127751.344 & 25.292 \\
ICP 3 & 683441.473 & 9127744.281 & 25.225 \\
ICP 4 & 683434.704 & 9127741.341 & 25.299 \\
ICP 5 & 683434.321 & 9127747.214 & 29.834 \\
ICP 6 & 683437.641 & 9127748.321 & 29.826 \\
ICP 7 & 683435.576 & 9127743.173 & 29.830 \\
ICP 8 & 683439.468 & 9127745.652 & 29.849 \\
ICP 9 & 683437.891 & 9127749.442 & 31.454 \\
ICP 10 & 683433.456 & 9127747.271 & 31.444 \\
ICP 11 & 683435.559 & 9127743.332 & 31.491 \\
ICP 12 & 683439.363 & 9127745.498 & 31.492 \\
\hline \hline
\end{tabular}

Persebaran titik GCP dan ICP ditunjukkan pada gambar berikut.

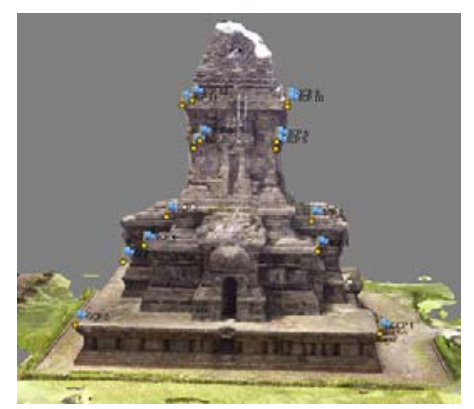

Gambar 3.5 Persebaran GCP dan ICP Tampak Depan

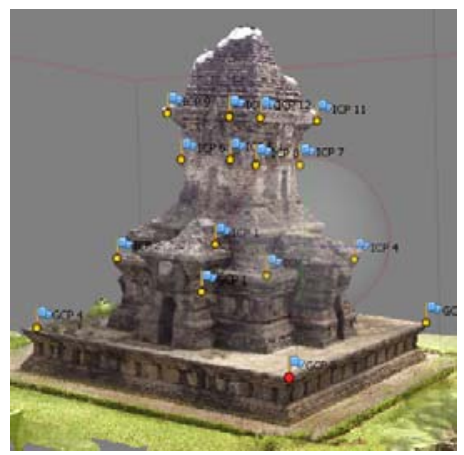

Gambar 3.6 Persebaran GCP dan ICP Tampak Belakang 
Sedangkan pada model rekonstruksi 3D Candi Singasari, nilai koordinat ICP diambil dari data point clouds. Hasil ICP dari pemodelan rekonstruksi 3D sebagai berikut.

\section{Evaluasi Pemodelan Rekonstruksi 3D Candi Singasari}

Pada penelitian ini, evaluasi rekonstruksi 3D Candi Singasari meliputi dua aspek, yaitu:

1. Aspek visual rekonstruksi 3D

2. Perhitungan nilai ketelitian geometrik

Parameter evaluasi pemodelan rekonstruksi 3D Candi Singasari mengacu pada klasifikasi level of detail (LOD) sebagai berikut.

Tabel 3.7 Kriteria LOD

\begin{tabular}{|c|c|c|c|c|}
\hline Aspek & LOD 1 & LOD 2 & LOD 3 & LOD 4 \\
\hline Skala Model & kota, regional & $\begin{array}{l}\text { distrik dalam } \\
\text { kota }\end{array}$ & $\begin{array}{l}\text { model asristektur } \\
\text { (eksteriror), } \\
\text { landmark }\end{array}$ & $\begin{array}{c}\text { model } \\
\text { arsitektur, } \\
\text { termasuk } \\
\text { interior }\end{array}$ \\
\hline Kelas Akurasi & rendah & menengah & tinggi & sangat tinggi \\
\hline Akurasi Posisi & 5 meter & 2 meter & 0,5 meter & 0.2 meter \\
\hline Generalisasi & $\begin{array}{c}\text { objek } \\
\text { berukuran }> \\
6 \times 6 \text { meter }\end{array}$ & $\begin{array}{c}\text { objek } \\
\text { berukuran }> \\
4 \times 4 \text { meter }\end{array}$ & $\begin{array}{l}\text { objek sebagai fitur } \\
\text { nyata }>2 \times 2 \text { meter }\end{array}$ & $\begin{array}{c}\text { elemen - } \\
\text { elemen } \\
\text { konstruktif } \\
\text { ditampilkan }\end{array}$ \\
\hline $\begin{array}{l}\text { Instalasi } \\
\text { Bangunan }\end{array}$ & - & - & $\begin{array}{l}\text { efek visual } \\
\text { eksterior } \\
\text { representatif }\end{array}$ & $\begin{array}{c}\text { objek dalam } \\
\text { bentuk } \\
\text { ukuran } \\
\text { sebenarnya }\end{array}$ \\
\hline Struktur & datar & $\begin{array}{l}\text { tipe dan } \\
\text { orientasi }\end{array}$ & $\begin{array}{c}\text { sesuai bentuk } \\
\text { objek sebenarnya }\end{array}$ & $\begin{array}{c}\text { sesuai bentuk } \\
\text { objek } \\
\text { sebenarnya }\end{array}$ \\
\hline
\end{tabular}

Proses filtering untuk visual rekonstruksi 3D bertujuan untuk membuang titik yang tidak diperlukan (noise) dari point clouds. Selain itu, proses ini digunakan agar visual rekonstruksi 3D terlihat rapi dan bersih. Gambar berikut menunjukkan visual rekosntruksi 3D Singasari sebelum dan sesudah proses filtering.

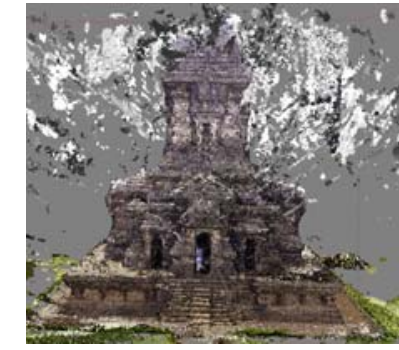

Gambar 3.7 Sebelum Proses Filtering

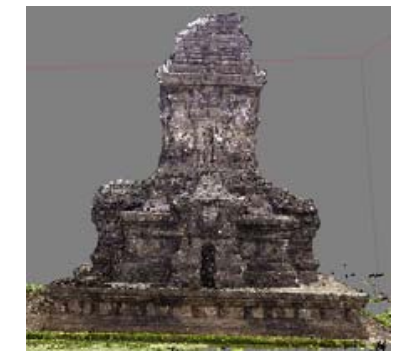

Gambar 3.8 Sesudah Proses Filtering
Proses filtering berdampak pada berkurangngnya jumlah point clouds yang pada awalnya berjumlah 434.956 titik menjadi 308.248 titik atau berkurang $29.13 \%$.

Perhitungan nilai ketelitian geometrik dilakukan dengan membandingkan ICP hasil dari pemodelan rekonstruksi 3D terhadap ICP ukuran dari lapangan. Perhitungan nilai ketelitian geometrik dilakukan dengan menghitung uji nilai korelasi, Root Mean Square Error (RMSE), dan uji standar kesalahan.

Pada penelitian ini, uji nilai korelasi yang digunakan adalah uji nilai korelasi pearson. Uji nilai korelasi pearson digunakan untuk mengetahui keeratan hubungan antar dua variabel (ukuran linier dua variabel).

Hasil perhitungan uji nilai korelasi adalah ICP koordinat easting sebesar 0.998, koordinat northing sebesar 0.997, dan koordinat Z sebesar 0.998. Berdasarkan dari hasil uji nilai korelasi menunjukkan bahwa ICP koordinat easting memiliki hubungan yang kuat (keterkaitan) begitu juga pada koordinat northing dan Z. Seangkan untuk hasil perhitungan RMSE ICP sebagai berikut.

Tabel 3.8 Nilai RMSE ICP

\begin{tabular}{cccc}
\hline \hline Titik & Easting (m) & $\begin{array}{c}\text { Northing } \\
(\mathbf{m})\end{array}$ & $\mathbf{Z}(\mathbf{m})$ \\
\hline ICP 1 & 0.181 & 0.170 & 0.152 \\
ICP 2 & 0.192 & 0.131 & 0.181 \\
ICP 3 & 0.317 & 0.199 & 0.120 \\
ICP 4 & 0.142 & 0.153 & 0.193 \\
ICP 5 & 0.201 & 0.408 & 0.124 \\
ICP 6 & 0.307 & 0.145 & 0.120 \\
ICP 7 & 0.122 & 0.133 & 0.119 \\
ICP 8 & 0.119 & 0.156 & 0.140 \\
ICP 9 & 0.088 & 0.148 & 0.216 \\
ICP 10 & 0.105 & 0.252 & 0.231 \\
ICP 11 & 0.017 & 0.064 & 0.185 \\
ICP 12 & 0.042 & 0.146 & 0.180 \\
RMSE & $\mathbf{0 . 1 7 7}$ & $\mathbf{0 . 1 9 4}$ & $\mathbf{0 . 1 6 8}$ \\
\hline \hline
\end{tabular}

Sedangkan uji standar kesalahan adalah uji standar kesalahan yang umumnya digunakan untuk mengevaluasi hasil pengukuran yang akan diterima maupun yang ditolak. Pada penelitian ini uji standar kesalahan menggunakan tingkat kepercayaan 90\%. Hasil perhitungan uji standar kesalahan sebagai berikut.

Tabel 3.9 Uji Standar Kesalahan Koordinat Easting dan Northing

\begin{tabular}{|c|c|c|c|c|c|c|}
\hline Titik & $\begin{array}{c}\text { Error } \\
\text { Easting }\end{array}$ & $\begin{array}{c}\text { Keteranga } \\
\mathbf{n}\end{array}$ & $\begin{array}{c}\text { Error } \\
\text { Northin } \\
g\end{array}$ & $\begin{array}{c}\text { Keteranga } \\
\mathbf{n}\end{array}$ & $\begin{array}{c}\text { Error } \\
\mathrm{Z}\end{array}$ & $\begin{array}{c}\text { Keteranga } \\
\mathbf{n}\end{array}$ \\
\hline ICP 01 & 0.181 & Diterima & 0.170 & Diterima & $\begin{array}{c}0.15 \\
2\end{array}$ & Diterima \\
\hline ICP 02 & 0.192 & Diterima & 0.131 & Diterima & $\begin{array}{c}0.18 \\
1\end{array}$ & Diterima \\
\hline ICP 03 & 0.317 & $\begin{array}{c}\text { Tidak } \\
\text { Diterima }\end{array}$ & 0.199 & Diterima & $\begin{array}{c}0.12 \\
0\end{array}$ & Diterima \\
\hline ICP 04 & 0.142 & Diterima & 0.153 & Diterima & $\begin{array}{c}0.19 \\
3\end{array}$ & Diterima \\
\hline ICP 05 & 0.201 & Diterima & 0.408 & $\begin{array}{c}\text { Tidak } \\
\text { Diterima }\end{array}$ & $\begin{array}{c}0.12 \\
4\end{array}$ & Diterima \\
\hline ICP 06 & 0.307 & $\begin{array}{c}\text { Tidak } \\
\text { Diterima }\end{array}$ & 0.145 & Diterima & $\begin{array}{c}0.12 \\
0\end{array}$ & Diterima \\
\hline ICP 07 & 0.122 & Diterima & 0.133 & Diterima & $\begin{array}{c}0.11 \\
9\end{array}$ & Diterima \\
\hline ICP 08 & 0.119 & Diterima & 0.156 & Diterima & $\begin{array}{c}0.14 \\
0\end{array}$ & Diterima \\
\hline ICP 09 & 0.088 & Diterima & 0.148 & Diterima & $\begin{array}{c}0.21 \\
6\end{array}$ & Diterima \\
\hline ICP 10 & 0.105 & Diterima & 0.252 & Diterima & $\begin{array}{c}0.23 \\
1\end{array}$ & $\begin{array}{c}\text { Tidak } \\
\text { Diterima }\end{array}$ \\
\hline ICP 11 & 0.017 & Diterima & 0.064 & Diterima & $\begin{array}{c}0.18 \\
5\end{array}$ & Diterima \\
\hline ICP 12 & 0.042 & Diterima & 0.146 & Diterima & $\begin{array}{c}0.18 \\
0\end{array}$ & Diterima \\
\hline
\end{tabular}

*) Inteval kesalahan koordinat Easting: $3.40 \times 10^{-5}<\mathrm{e}<3.05 \times 10^{-1}(\mathrm{~m})$

*) Inteval kesalahan koordinat Northing: $3.50 \times 10^{-2}<\mathrm{e}<3.16 \times 10^{-1}(\mathrm{~m})$

*) Inteval kesalahan koordinat Z: $0.098<\mathrm{e}<0.229$ (m) 
Berdasarkan hasil uji standar kesalahan diperoleh koordinat easting yang diterima sejumlah 10 titik $(83 \%)$, koordinat northing yang diterima sejumlah 11 titik (91.7\%), dan koordinat $\mathrm{Z}$ yang diterima sejumlah 11 titik (91.7\%).

\section{KESIMPULAN}

Pada penelitian ini, kesimpulan yang dapat diambil sebagai berikut.

1. Visualisasi rekonstruksi 3D struktur Candi Singasari menggunakan metode aerial videogrametri berhasil dilakukan. Hasil evaluasi rekonstruksi 3D struktur Candi Singasari menghasilkan bentuk point cloud sejumlah 308.248 titik, dense cloud sejumlah 1.126.457 titik, dan textured yang meliputi 225.291 titik (permukaan/face) dan 113.595 vertex dari 161 frame video dengan rata-rata fitur deteksi tiap frame video sejumlah 2.242 titikyang diolah menggunakan konsep structure from motion (SfM).

2. Bentuk visualisasi model 3D Candi Singasari sudah memenuhi syarat LOD orde 3 dengan kriteria RMSE $<0.5$ meter, yaitu RMSE easting sebesar 0.177 meter, RMSE northing sebesar 0.194 meter, dan RMSE Z sebesar 0.168 meter, efek visual eksterior representasif, dan visualisasi struktur Candi Singasari sesuai dengan objek sebenarnya (gambar 3.5; 3.6; 3.8).

3. Evaluasi untuk validasi nilai geometrik struktur Candi Singasari yang diperoleh dari hasil korelasi dan uji standar kesalahan. Hasil korelasi antara variabel ICP ukuran model rekonstruksi 3D terhadap ukuran di lapangan menunjukkan nilai kolerasi untuk koordinat easting sebesar 0.998, koordinat northing sebesar 0.997 dan koordinat $\mathrm{Z}$ sebesar 0.998, artinya nilai korelasi tersebut menunjukkan hubungan keeratan yang kuat dari variabel - variabel tersebut. Adapun nilai uji standar kesalahan untuk koordinat easting diterima $83 \%$, koordinat northing diterima $91.7 \%$, dan koordinat $\mathrm{Z}$ diterima $91.7 \%$

\section{UCAPAN TERIMAKASIH}

Penulis Y. P. mengucapkan terima kasih kepada kantor BPCB (Balai Pelestarian Cagar Budaya) Kabupaten Mojokerto dan pengurus Candi Singasari, Malang, Jawa Timur atas ijin dan bantuannya selama proses pembuatan penelitian ini.

\section{DAFTAR PUSTAKA}

[1] Sayekti, S. I., Amiuza, C. B. \& Sujudwijono, N., 2014. Geometri Fraktal pada Candi Singosari sebagai Konsep Desain Museum Purbakala Singosari. Jurnal Mahasiswa Jurusan Teknik Arsitektur, Volume 2.

[2] Tian, Y., 2011. Building Reconstruction from Terrestrial Video Image Sequences. Twente: University of Twente Faculty of Geo-information Science and Earth Observation.

[3] Snavely, N., 2010. Scene Reconstruction and Visualization from Internet Photo Collections. s.l., Proceedings of the IEEE.

[4] Westobya, M. et al., 2012. 'Structure-from-Motion' photogrammetry: A low-cost, effective tool for geoscience applications. Elseiver, Volume 179, pp. 300-314.

[5] Fan, H. \& Meng, L., 2009. Automatic Derivation of Different Levels of Detail for 3d Buildings Modeled by City-Gml, Munich: International
Graduate School of Science and Engineering Department of Cartography, Technische Universität München Arcisstr.

[6] Rashidi, A., Dai, F., Brilakis, I. \& Vella, P., 2013. Optimized Selection of Key Frames for Monocular Videogrammetric Surveying of Civil Infrastructure. Elsevier, pp. 270-282.

[7] Ghilani, C. D. \& Wolf, P. R., 2012. Elementary Surveying an Introduction to Geomatics. 13 ed. New Jersey: Pearson Education Inc..

[8] Rashidi, A., 2014. Improved Monocular Videogrammetry for Generating 3D Dense Point Clouds of Bulit Infrastructure. Georgia: Georgia Institute of Technology.

[9] Berlin, A. T., 1992. Fundamentals of Remote Sensing and Airphoto Interpretation. 5 ed. New Jersey: Prentice Hall.

[10]Lowe, D. G., 2004 . Object Recognition fom Local Scale-Invatiant Features. International Journal of Computer Vision 60, pp. 91-110.

[11] Abidin, H., 2007. Penentuan Posisi dengan GPS dan Aplikasinya. Jakarta: Pradnya Paramita.

[12] Supadiningsih, C. N., 2004. Modul Ajar Ilmu Ukur Tanah I. Surabaya: Program Teknik Geodesi-ITS. 